\title{
A précis of Free Time
}

\author{
JULIE L. ROSE \\ Dartmouth College
}

Every citizen is entitled, as a matter of justice, to a fair share of free time. This is the core argument of Free Time. The argument rests on the widely held commitment to ensuring that citizens possess the means to exercise their freedoms, rooted in the recognition that if citizens lack the means to make effective use of their formally guaranteed freedoms, those freedoms are of little worth. A foundational tenet of liberal egalitarian theories of justice is, as such, what I term the effective freedoms principle: citizens have legitimate claims to a fair share of the resources generally required to exercise their formal liberties and opportunities.

Though the effective freedoms principle is applied most often to citizens' requirements for material resources, it applies in the same way to the resource of free time: time that is not consumed by meeting the necessities of life, that one can devote to one's own pursuits and commitments. This argument has been overlooked, yet it is readily apparent on reflection. Consider, for instance, how, in order to exercise one's right to vote, one must have not only the means to get to the polls, but also the free time to do so. Citizens generally require free time to make effective use of the full range of their fundamental liberties, as well as any of their broader legal freedoms and opportunities. As such, I argue, on the basis of the effective freedoms principle, citizens have legitimate claims to the resource of free time.

Though this argument has been absent from contemporary liberal theories of justice, it can be found in a recognizable form in the arguments of American nineteenth century labor reformers in their fight for time. For citizens to enjoy their rights to "life, liberty, and the pursuit of happiness," insisted "The Working Men's Declaration of Independence," they must have the "means" to make use of them. " "It is true", they argued, "that churches are erected, school houses are built, mechanics' institutes are founded and libraries ready to receive us ... but alas! We lack the time to use them - time". ${ }^{2}$ Workers required free time not only to make use of their fundamental political, associational, and religious liberties, but more

1 “The Working Men's Declaration of Independence”, December 1829 in Foner (1976: 49) original emphasis.

2 W. Sylvis (1968: 199) original emphasis; quoted in Roediger and Foner (1989: 99). 
broadly to pursue any of their own ends, as encapsulated in their demand for "eight hours for work, eight hours for rest, and eight hours for what we will". ${ }^{3}$

Though ensuring that citizens enjoy the means to make use of their freedoms is a central liberal egalitarian commitment, contemporary liberal theories of justice have given little attention to "hours for what we will". Instead, they have implicitly assumed that free time is not an appropriate or worthy concern of a liberal theory of justice. Given this incongruity, it is worth considering why. It owes, I argue, to two mistaken views.

The standard liberal egalitarian approach to distributive justice, which I label liberal proceduralism, is to ensure a fair distribution of resources, the all-purpose means that are generally required to pursue any conception of the good, in order to ensure that citizens have fair access to various specific goods, or the particular components of one's particular conception of the good. This approach - with which my argument has no quarrel aims to secure the just background conditions within which citizens can pursue their own ideas of the good life. Importantly, on this standard approach, for the state to directly target the distribution of specific goods is presumptively inappropriate. Absent some exceptional justification, the proper aim is instead to ensure a just distribution of all-purpose means.

The first mistake explaining the neglect of free time is that political philosophers have generally conceptualized it in terms that render it a specific good. ${ }^{4}$ Leisure has been variously understood as time engaged in intrinsically valuable activities, or as time in play and recreation, or - most common among theorists of distributive justice - as time not engaged in paid work, and on each understanding, as a specific good. (To keep this distinction clear, I use leisure to refer to the specific good and free time the resource). This limited view is, however, an error, for it overlooks the way, captured in the appeal for "hours for what we will", that free time is itself an all-purpose means.

Free time - understood specifically as time not committed to meeting one's own, or one's dependents', basic needs, which are the needs one must generally meet to attain a basic level of functioning in one's society - is, I argue, properly regarded as a resource. It is a necessary input that is

3 Rosenzweig (1983); see also Gourevitch (2015: 126-32, 144-45); Hunnicutt (2013: $1-94)$.

4 Goodin et al.'s Discretionary Time is an important and notable exception (Goodin et al. 2008). My conception of free time, though it departs from their account, is indebted to their view of discretionary time as time not consumed by the necessities of life. For another account that draws on Goodin et al.'s conception, see Shippen (2014). 
generally required to pursue any conception of the good, and it meets the conditions to be an object of a public and feasible theory of justice.

The second mistake is the implicit assumption, stemming from the economic view of time and money as fungible goods, of what I call the time-money substitutability claim: that realizing a just distribution of income and wealth is sufficient to ensure a just distribution of free time. If this claim were true, it would not be necessary to give any distinct attention to free time as an object of justice. Yet, neither of the assumptions on which the claim depends - the perfect divisibility of labor demand and the perfect substitutability of money and basic needs satisfaction - can be sustained. Given both ethical and empirical limitations of economic markets, individuals cannot always unobjectionably purchase the satisfaction of their own, or their dependents', basic needs, nor can they always freely choose to reduce their hours of paid work to the level they prefer (even for a corresponding reduction in pay, a phenomenon economists term overemployment).

With these obstacles cleared, it is then possible to construct the core argument for citizens' claims to free time. First, free time is itself a resource. Second, if a theory of justice endorses the effective freedoms principle, as all liberal egalitarian theories do, then citizens have legitimate claims, as a matter of justice, to fair shares of free time. Further, to ensure that citizens have their fair shares, free time must be treated as a distinct object of justice.

Ensuring that citizens have their fair shares of free time requires, if everyone's fair share is, say, eight hours per day, ensuring that all citizens are able to meet their basic needs in sixteen hours per day (e.g. with income subsidies or in-kind provisions), as well as protecting citizens' ability to choose to spend no more than this time meeting their basic needs (e.g. with work hours regulations). Moreover, citizens must not only have the requisite amount of free time, they must enjoy it on conditions that allow them to effectively use it to exercise their liberties, which include having access to generally usable periods of free time on predictable schedules.

With the central argument in place, I turn then to developing some of its implications in the later chapters. Chapter 5 argues that, because citizens' exercise of their freedom of association, whether civic, religious, or social, generally requires sharing time together, citizens require access to free time shared with a significant portion of those with whom one currently associates and might associate. Access to shared free time may be realized by providing citizens with vast amounts of free time, greater work schedule flexibility, or a common period of free time. If the first is not an option, I argue that instituting a common period of free time across society - realized, for instance, with Sunday closing laws (in a modified form consistent with economic and 
religious liberty) - may be the best means of ensuring effective freedom of association in a pluralistic democratic society.

Chapter 6 turns to the question of whether parents and other caregivers are entitled to workplace accommodations that enable them to combine paid work, caregiving, and free time, such as paid leave and short and flexible hours schedules. I argue that they are, if citizens' claims to free time are developed such that: citizens have pro tanto claims to free time in their chosen occupations; and basic caregiving for children, like other dependents, is treated as a necessary activity that (to a point) deducts from free time. Taking on these terms, I argue that they yield a presumptive claim to be able to engage in paid work, basic caregiving, or the combination, while also having free time.

One final point to make is that the core argument - that citizens are entitled to a fair share of free time - holds on any theory that endorses the effective freedoms principle, as all liberal egalitarian theories do. Across this broad range of theories, the principle is recognized and developed in different ways. So that the core argument applies broadly, it is constructed to not depend on taking particular positions on a set of contested issues across these theories. The later chapters do take positions on some of these issues (most notably related to individual responsibility) in order to draw out some of the argument's implications, but one might adopt different positions and develop the core argument in other ways, yielding another set of implications. Indeed, once the core claim is recognized, citizens' claim to the resource of free time ought to be incorporated into theories of justice in a diverse and expansive array of ways.

\section{BIBLIOGRAPHY}

Foner, P.S., ed. 1976: We, the Other People. Urbana: University of Illinois Press.

Goodin, R.E, J.M. Rice, A. Parpo, and L. Eriksson, 2008: Discretionary Time: A New Measure of Freedom. Cambridge: Cambridge University Press.

Gourevitch, A., 2015: From Slavery to the Cooperative Commonwealth: Labor and Republican Liberty in the Nineteenth Century. Cambridge: Cambridge University Press.

Hunnicutt, B.K., 2013: Free Time: The Forgotten American Dream. Philadelphia: Temple University Press.

Roediger, D. R., and P.S. Foner, 1989: Our Own Time: A History of American Labor and the Working Day. London: Verso.

Rosenzweig, R., 1983: Eight Hours for What We Will: Workers and Leisure in an Industrial City, 1870-1920. Cambridge: Cambridge University Press.

Shippen, N.M., 2014: Decolonizing Time: Work, Leisure, and Freedom. New York: Palgrave Macmillan.

Sylvis, W., 1968: “Address Delivered at Boston, January 1867.” In The Life, Speeches, Labors and Essays of William H. Sylvis, edited by J.C. Sylvis. 1872. Reprint, New York: Augustus M. Kelley. 